\title{
Kindness at School: What Children's Drawings Reveal About Themselves, Their Teachers, and Their Learning Communities
}

\author{
John-Tyler Binfet
}

John-Tyler Binfet, PhD, is an assistant professor in the Faculty of Education at the University of British Columbia, Okanagan in Kelowna, BC. His research explores students' and teachers' perceptions of kindness within the context of classrooms and schools. He is the lead author of the School Kindness Scale, a 5-item measure that assesses students' perceptions of school kindness. In addition to his research on kindness, Dr. Binfet is the director of the Building Academic Retention through K9s (barkubc.ca) program and oversees 45 therapy dogs on campus who work to reduce stress and homesickness in first-year college students. Email: johntyler.binfet@ubc.ca

This study examined how students in kindergarten through third grade conceptualized kindness in school. Participants were asked to draw two pictures: one of themselves doing something kind at school, and one of a teacher doing something kind. Students' drawings of their kindness reflected themes of maintaining friendships, physically helping others, and showing respect. Students' drawings of teacher kindness revealed that students saw teaching itself as an act of kindness and that teachers showed kindness through physically helping others. Across drawings, no gender differences were found; however, differences in the themes emphasized by grade were identified.

Keywords: kindness, elementary students, teacher behaviour, prosocial behaviour
There is ample discussion in schools around how to best promote students' prosocial behaviours, such as kindness, yet little is empirically known about how students themselves perceive and manifest kindness within the school context. A review of extant educational and psychological literature revealed that, other than a pilot study related to this project (Binfet \& Gaertner, 2015), no studies have investigated how students conceptualize kindness in school and how students perceive kindness in their teachers. Though kindness has not been extensively examined from the perspective of young students, it nevertheless is a term frequently discussed in broader academic contexts alongside altruism and compassion (Campos \& Algoe, 2009). Kindness in children has also been discussed and situated within the context of empathy, with authors such as Eisenberg, Fabes, and Spinrad (2006) and Greenberg and Turksma (2015) positing that kindness, or prosocial behaviour, arises when children are encouraged to be empathic. Kindness was chosen as a distinct construct for the present study because it is a familiar term to children that is commonly used in schools.

Though kindness is a ubiquitous term used in both parenting and education, few definitions of kindness have been proffered, and the majority of published definitions reflect adult perspectives on what it means to be kind (for a review of definitions, see Binfet, 2015). Peterson and Seligman (2004) define kindness as simply "doing favors and good deeds for others" (p. 296). Long (1997) defines kindness as having a foundation in compassion and says that when we "act on this feeling of compassion in a helpful and caring way, this behaviour becomes an act of kindness" (p. 243). More recently, Kerr, O'Donovan, and Pepping (2014) argued that "kindness is a combination of emotional, behavioural, and motivational components" and consists of "behaviours that benefit other people, or make others happy" (p. 20). Definitions of kindness reflecting children's perspectives are less common, and a pilot study on kindness in young students by the author and his graduate student researcher generated the following definition: "Kindness, from the perspective of young children, is an act of emotional or physical support that helps build or maintain relationships with others" (Binfet \& Gaertner, 2015, pp. 36-37).

More research on kindness is needed that reflects the perspectives of school-age children to inform both children and the adult agents within schools whose mission is often to promote kind behaviour and interactions among students. In addition to the need to identify how children enact kindness in school, it is also important to understand how students perceive the prosocial behaviour of their teachers and other significant adults (e.g., school counsellors and school administrators) who serve as key agents of influence and support for children living in fast-paced environments where working parents and single-parent families can be commonplace. Teachers, especially, serve as behavioural models for students and hold potential to encourage prosocial behaviours such as kindness through their modelling of acts of kindness. The potential of teachers to model prosocial behaviour to children is supported by research highlighting the influence teachers have in shaping students' behaviour (Bricheno \& Thornton, 2007; Dar, 2015). In seminal research by Rushton (1980) and by Lipscomb, 
Larrieu, McAllister, and Bregman (1982) examining the effects of models of generosity versus models of selfishness, it was found that generosity increased when children were exposed to models who behaved generously.

There are a number of reasons that parents and teachers should encourage kindness among the children under their care. As parents and educators strive to create conditions that promote optimal growth and development, practicing kindness has been argued to encourage a focus away from the self to include others and to push aside negative emotions (Anderson, 2003). Being kind has implications for wellbeing, including the encouragement of social bonds, the building of interpersonal trust and acceptance, and the development of personal skills (Kerr et al., 2014). Though Luks (1988) first coined the term helper's high to highlight the positive physical and emotional benefits arising from helping others, it was Post (2005) who wrote "Altruism, happiness, and health: It's good to be good," reinvigorating the discussion of the importance of being kind to others.

One way that teachers model prosocial behaviour, including kindness, for students is through their instruction in social and emotional learning (SEL). Teachers are increasingly providing instruction in SEL alongside the instruction of core academic subjects (Ashdown \& Bernard, 2012; Durlak, Weissberg, Dymnicki, Taylor, \& Schellinger, 2011; Jennings \& Greenberg, 2009; Schonert-Reichl, HansonPeterson, \& Hymel, 2015). This promotion of students' social and emotional development- the extent to which students are able to manage their emotions, demonstrate empathy, maintain satisfying relationships, and make responsible decisions (Collaborative for Academic and Social and Emotional Learning, 2015) - helps equip students with competencies that allow them to build resiliency and negotiate challenges and setbacks. The promotion of intentional prosocial behaviours, such as kindness, figures prominently in SEL, with SEL providing a theoretical framework for understanding kindness within the school context. Understanding how kindness is conceptualized and perceived by students has implications for educators seeking to foster prosocial behaviour in and among students and for the professional development of teachers seeking to model prosocial behaviour within school settings.

\section{What Influences Students' Kind Behaviour?}

Student behaviour results from individual characteristics (e.g., biological factors, role-taking abilities) interacting with both socialization and situational influences (Eisenberg et al., 2006; Spivak \& Farran, 2012). Social learning theory (Bandura, 1986; Staub, 1992) holds that role models within children's learning environments, whether they are adults or peers, serve to guide, encourage, and reinforce desired behaviour. Role models demonstrate behaviours that students may replicate, or they reinforce a behaviour (or potential behaviour) in students through their actions or words. Role models may also provide feedback about the behaviour of others being observed by students, or, more generally, about human actions and interactions found within the school context.

Given the importance of teachers in the lives of young students, children's academic and behavioural outcomes are, not surprisingly, strongly influenced by both teachers' instructional and emotional support (Hamre \& Pianta, 2005; Pianta, La Paro, Payne, Cox, \& Bradley, 2002). Instructional support includes literacy instruction, evaluative feedback, instructional conversation, and the encouragement of student responsibility, while emotional support includes teacher sensitivity, teacher detachment, quality of climate (positive or negative), classroom management, and the level of teacher control (Hamre \& Pianta, 2005). Teachers' instructional and emotional support provides a framework for the investigation of students' perceptions of teacher kindness.

Though a review of educational and psychological literature revealed a dearth of studies investigating students' perceptions of kindness at school, students have nevertheless been asked to share their views on teachers' prosocial behaviour. In her seminal examination of perceived pedagogical caring, Wentzel (1997) followed 248 students from sixth through eighth grade, administering a scale that assessed students' perceptions of their teachers as caring agents (e.g., "My teacher really cares about me"; "My teacher cares about how much I learn"). Students described caring teachers as using democratic approaches, having expectations for student behaviour, providing constructive feedback to students, and modelling a caring attitude toward their own work. McHugh and colleagues (2013) examined findings from 13 focus groups involving 14- to 20-year-olds and found that students saw teachers' "bridging" behaviours (behaviours in which teachers made intentional efforts to connect with students) as key to positive student-teacher relationships.

Conducting research examining school-based perceptions of young students is challenging. Emerging reading levels prohibit the completion of paper-and-pencil or electronic surveys, and interviews conducted by unfamiliar adults (i.e., researchers) can be intimidating, which, in turn, can inhibit students' willingness to share their insights and beliefs. Thus, researchers often use observational methodologies to assess the nature and quality of student-teacher interactions. For example, Spivak and Farran (2012) observed teachers going about their normal routine (a business-as-usual model) in order to shed light on young students' perceptions of the student-teacher relationship. In their observations of 124 first-grade classrooms ( $N=2,098$ students), they found that teachers' use of verbal encouragement influenced 
children's prosocial behaviour. Children were more likely to share, help, and cooperate with each other when their teachers actively guided students toward prosocial behaviour and empathy. Teachers' behaviours and characteristics that influenced students' perceptions of desired behavioural expectations in classrooms included use of emotional warmth, positive behaviour management strategies, encouragement of expressive language, use of vocabulary instruction, and verbally encouraging prosocial behaviour and empathy.

As previously noted, the frequency and consistency of contact between teachers and students affords teachers insights into not only students' learning and academic progress but also into students' social and emotional development. Through report cards or progress reports, teachers regularly assess and evaluate students and provide commentary on both students' academic progress and their schoolbased behaviour. Conversely, the frequency and consistency of contact between teachers and students also provides students with opportunities to observe, assess, and evaluate teachers' behaviours; however, students have few contexts to share these perceptions other than with peers or parents/guardians.

\section{The Pilot Study}

To assess the efficacy of a timed drawing exercise in order to access young students' perceptions of kindness at school, a pilot study was conducted (see Binfet \& Gaertner, 2015). One hundred and twelve kindergarten $(n=31)$, first $(n=34)$, and second grade $(n=47)$ students were recruited from seven classrooms in three elementary schools (mean class size was 18, range $=17-24$ ) in a small, middleclass, western Canadian city. Participants were asked to draw a definition of kindness ("What does kindness look like to you?") and a picture of something kind they had done at school recently. In situ coding was used during data collection that documented students' verbatim responses to "Who is in your drawing?" and "What is happening?" Students were given five minutes for each drawing.

Findings revealed that (a) students understood the task and were able to complete their drawings within the time restriction; (b) the combination of students' drawings and written descriptions provided rich data that could be coded through conventional content analysis; (c) physically helping others, giving, and doing kind acts that maintained friendships were themes most commonly found in students' drawings of what kindness looked like; and (d) physically helping others, including others, and doing acts to maintain friendship were prevalent themes in students' illustrations of the kind acts they performed at school.

\section{The Current Study}

Extending the method used in the pilot study, the aim of the current study was to use drawings to identify and examine young students' perceptions of kindnesses done by themselves and their teachers. Using drawing to access children's perceptions of lived experiences is gaining popularity across varied research disciplines (Einarsdottir, Dockett, \& Perry, 2009; Freeman \& Mathison, 2009; Harwood \& Copfer, 2015; Mathison, 2014). Drawing is a nonthreatening and familiar activity for children; thus, using drawing helps to create a comfortable research context (Weber, Duncan, Dyehouse, Strobel, \& Diefes-Dux, 2011). Drawing tasks are nonconfrontational; children can focus on drawing, rather than having to make eye contact or interact directly with the researcher (Einarsdottir et al., 2009). Precautions must be taken, though, when interpreting children's drawings. Adult perspectives can be markedly different from those of children; therefore, misinterpretations and/or distortions can occur when adults attempt to make sense of children's drawings (Bosacki, Harwood, \& Sumaway, 2012; Yurtal \& Artut, 2010). A drawing-telling methodology in which the child describes the contents of their drawing and the researcher documents these descriptions as a means of informing the interpretation of drawings can help decrease the likelihood of misinterpretation (Einarsdottir et al., 2009; Wright, 2007). Mitchell and colleagues (2011) describe the benefits of this "drawing-talking" approach, saying that "drawing as a research tool is often complemented by verbal research methods (Guillemin, 2004) that encourage collaborative meaning-making that allows the drawer to give voice to what the drawing was intended to convey" (p. 20).

In accord with findings by Eisenberg and colleagues (1999) and Hamre and Pianta (2005) identifying examples of students' prosocial behaviour, and in concert with findings from the pilot study, it was first hypothesized that students' examples of kindness would contain the prevalent themes of helping, sharing, and cooperating. Second, it was hypothesized that students' examples of teacher kindness would reflect themes of instructional and emotional support, as identified by Hamre and Pianta (2005). 


\section{Method}

\section{Recruitment of Participants}

This research complied with university and school district research ethics. All kindergarten to third-grade teachers in the public school district of a mid-sized, predominantly middle-class city in western Canada were sent an electronic flyer describing the study and asking for participants. The first 40 teachers to respond were included in the study (one teacher withdrew from the study due to illness). Thirty-nine teachers completed consent forms and sent parent consent forms home with students, of whom $96 \%$ were given consent to participate. Given participants' young ages, students were asked to provide verbal assent prior to participation in the study. Teachers received a modest bookstore gift card as compensation for their participation.

\section{Participants}

Participants $(N=652)$ included students in kindergarten $(n=148,22 \%)$, first grade $(n=161,25 \%)$, second grade $(n=134,21 \%)$, and third grade $(n=209,32 \%)$. The mean number of students per class was 19 (range $=15-26) ; 50.2 \%$ of participants were female, $82 \%$ were Caucasian, and the mean age was 7.4 years $(S D=1.21$, range $=5.25-9.33)$. The majority of participants were of European Canadian origin and spoke English as a first language.

\section{Procedure}

A kindness drawing instrument was administered by the author and two undergraduate research assistants to participants in small groups of five outside of their classroom (e.g., in a nearby resource room or the library) and without the classroom teacher present. Scripted directions were read aloud to students and an inclusive approach to capturing the views of all students in each participating classroom was taken, with students with exceptionalities invited to take part in the study.

Participants were asked to draw two pictures: one a self-image performing an act of kindness and the other of their teacher performing an act of kindness. Participants were not given a definition of kindness and were given five minutes to complete each drawing. In contrast to designs employing smaller sample sizes that afford researchers time to engage students in discussions to probe and contextualize their drawings, the aim of this research was to build on the pilot study method and findings and efficiently sample large numbers of early elementary students (versus capturing in-depth participant narrations of a few students). Upon completion of each drawing, participants were asked: "Who is in your drawing?" and "What is happening in your drawing?" Participants' responses were recorded by the researchers below the drawing exactly as stated by the participant, and member checking was done by reading the written descriptions aloud to each participant for confirmation of content.

\section{Measures}

Demographic information. Participants were asked aloud to provide demographic information regarding their age, grade, and family composition (e.g., "Who lives in your house with you?"). Participants' demographic information was subsequently verified by school records provided by the classroom teacher.

Kindness drawings. Participants were provided with two sheets of paper, each containing a large empty box (see Figure 1), one for each of their kindness drawings. The development of this "scale" was in alignment with other researchers who used drawings to capture students' conceptualizations of school-situated concepts (e.g., teasing in Bosacki et al., 2012; bullying in Andreou \& Bonoti, 2009; school violence in Yurtal \& Artut, 2010; and perceptions of school in Gamradt \& Staples, 1994). For each drawing, participants were prompted to draw using an open-ended request in accordance with protocols developed by Haney, Russell, and Bebell (2004). For drawing No. 1, the prompt was "In the box below, draw a picture of something you have done kind at school recently. What have you done to show kindness at school?" (See Figures 1 and 2 for examples.) For drawing No. 2, the prompt was: "Draw a picture that shows a teacher doing something kind. What might a teacher do to show kindness at school?” (See Figures 3 and 4 for examples.) 
Step\#1: In the box below, draw a picture of something you have done kind at school recently. What have you done to show kindness at school?

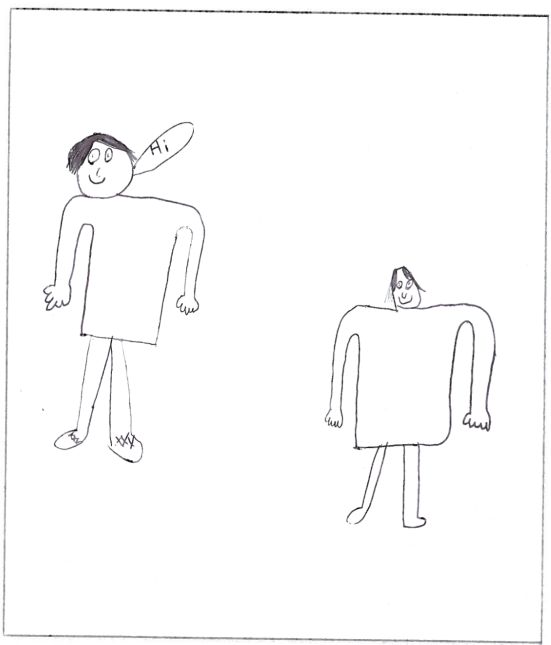

wн?: $\frac{\text { Self } t \text { random student }}{\text { what? Iin saying "tli" to make someone }}$

Figure 1. Drawing of students' perception of kindness in themselves (boy, second grade).

Step \#2: Draw a picture that shows a teacher doing something kind. What might a teacher do to show kindness at school?
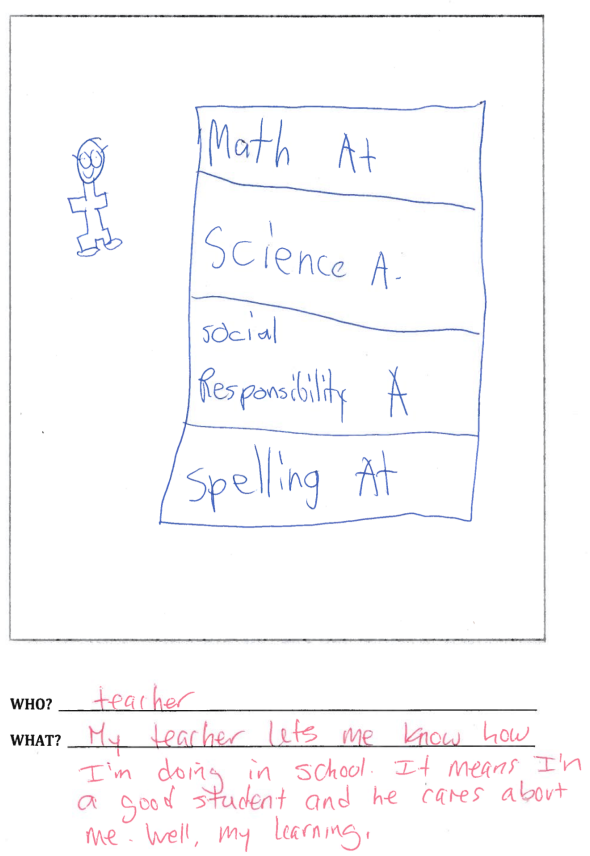

Figure 3. Drawing of students' perception of teacher kindness (boy, third grade).
Step\#1: In the box below, draw a picture of something you have done kind at school recently. What have you done to show kindness at school?

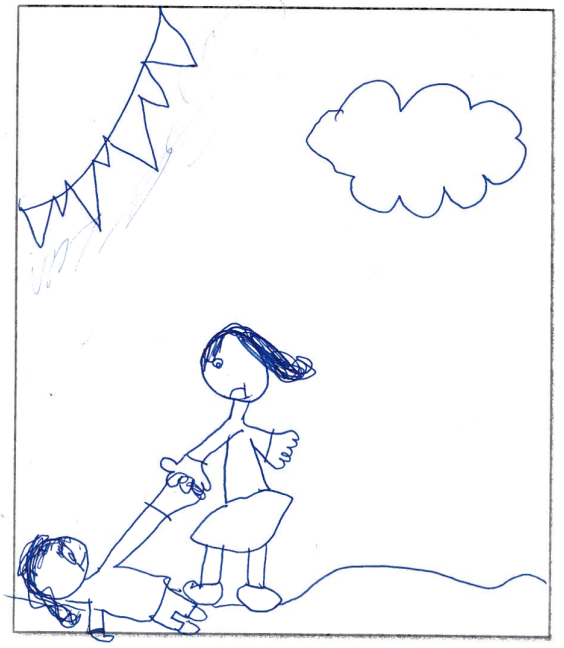

wно? Self $\pi$ Friend

WHAT? I an heping somone up when They fell

Figure 2. Drawing of students' perception of kindness in themselves (girl, third grade).

Step \#2: Draw a picture that shows a teacher doing something kind. What might a teacher do to show kindness at school?

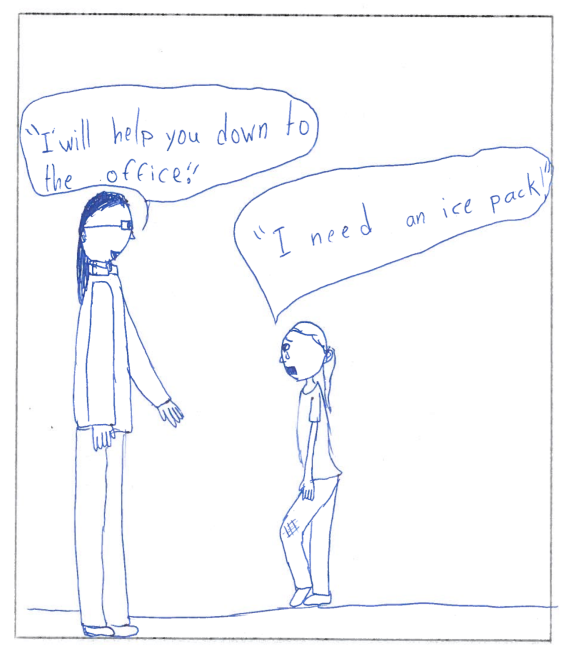

wH0? self + teacher
wHAT? teacher helped me down to the office to grab an ice pack
because I hurt my leg.

Figure 4. Drawing of students' perception of teacher kindness (girl, third grade). 


\section{Analytic Methodology}

Three levels of analysis were performed on each participant's drawings. First, following methodology utilized in previous research analyzing drawings by elementary students (Bosacki, Varnish, \& Akseer, 2008; Bosacki et al., 2012; Richer, 1990), participants' drawings were analyzed for their pictorial content. This involved identifying (1) whether the child included him or herself within the illustration; (2) who was in each drawing (e.g., self alone, self and classmate, self and teacher); and (3) the location or context in which the act of kindness was situated (e.g., school in general, classroom, playground). Second, qualitative conventional content analysis (Hsieh \& Shannon, 2005) was used to identify the primary and secondary themes within each drawing. And last, to more fully understand participants' interpretations of kindness, examples of students' descriptions of their drawings were identified for the top thematic categories.

Identification of themes. Conventional qualitative content analysis was used to code and identify themes and patterns because it is best suited to capturing prevalent themes found within participant-generated data (Hsieh \& Shannon, 2005) and where there is a dearth of predetermined thematic categories derived from previous research.

Separate coding categories were generated to identify the themes found within drawing No. 1 (kindness done by self) and drawing No. 2 (kindness done by teacher). This involved the following two-step process: (1) for each category of drawings, two independent raters (the author and a trained graduate research assistant) coded a subsample of $20 \%$ ( $n=130$ for each drawing task) of randomly selected drawings to identify global or general themes; and (2) raters then met to compare themes and collaboratively winnow them into categories to reduce redundancy (Wolcott, 1990). For drawing No. 1, a total of 18 global themes were identified and winnowed to 9 categories; for drawing No. 2, 24 global themes were winnowed to 11 categories (see Table 1).

Once the categories were identified, drawings were independently analyzed by both raters for their thematic content (Bosacki et al., 2012). Both primary and secondary themes were identified for each drawing. Where no secondary theme was evident, the code "no theme evident" was assigned. Interrater agreement was $80 \%$ across drawings.

\section{Results}

\section{Drawing No. 1: Kindness Done by Self}

Pictorial depictions. The majority of participants (89\%) followed directions and drew themselves when illustrating their act of kindness done in school. Most participants (95\%) included other individuals in their drawings (e.g., friends and classmates), and almost half of the participants (44\%) situated their kind acts within the general school context. Depictions of kind acts outside of school (e.g., in school parking lot or in adjacent field) followed by kind acts situated at the school playground were also evident ( $30 \%$ and $14 \%$ respectively).

Thematic content and descriptions. The majority of students drew kind acts reflecting the themes of maintaining friendships (54\%), followed by those of physically helping others (14\%) and showing respect (12\%).

Participants predominantly depicted and described kindness as acts that maintained friendships. For example, "We are asking another friend to come play with us." (\#153), "I'm sharing a ball with him, which makes him happy." (\#551), and "This is me including a lonely student." (\#595). This theme was followed by the theme of physically helping other students, which was reflected in comments such as "I'm helping a student who is hurt. I am getting a supervisor." (\#447) and "My friend fell and I'm helping him by getting an ice pack." (\#359). Showing respect was the next most prevalent theme illustrated by participants and was reflected by comments such as "We're picking up trash because it’s important to show respect to the school." (\#159) and "I'm saying thank you to my friend." (\#267).

Analysis by gender and grade. Given that the top two primary and secondary themes accounted for the majority of responses in each category ( $68 \%$ and $52 \%$ respectively, see Table 2$)$, further analyses were conducted only on these themes.

Gender did not have a significant influence on the primary theme, $\chi^{2}(1, N=89)=.25, p=.62$, although grade had a moderate influence, $\chi^{2}(3, N=89)=13.80, p=.003, V=39$ (a moderate effect size; Rea \& Parker, 1992). Examination of the contingency table revealed that the likelihood that participants' drawings would reflect the theme of "friendship" was not significantly different across grades (standardized residuals $z \mathrm{~s}<1.96$ ). The significant influence of grade can be accounted for by the unusual distribution of "helping 
physically" as the primary theme: although "helping physically" was reflected in $15 \%$ of the kindergarten drawings and $25 \%$ of the third-grade drawings (an insignificant difference, respective $z \mathrm{~S}=-.5, .5$ ), this theme was reflected in $42 \%$ of the second grade drawings $(z=2.3)$ but in none of the first-grade drawings $(z=2.2)$. Chi square analyses of the top two secondary themes revealed that gender did not have a significant influence on the secondary theme, $\chi^{2}(1, N=68)=.38, p=.61$, nor did grade, $\chi^{2}(3, N=68)=3.61, p=.31$.

\section{Drawing No. 2: Kindness Done by Teachers}

Pictorial depictions. When asked to draw a teacher doing something kind at school, the majority of participants (48\%) did not include themselves in their drawings. Of those who included students in their drawings of teacher kindness, $37 \%$ of participants drew themselves interacting with a teacher, followed by teachers interacting with classmates (20\%). Participants situated teachers' kind acts predominantly within the context of the classroom (40\%), followed by the general school context (34\%; e.g., hallway), and then teachers performing kind acts outside (26\%).

Thematic content and descriptions. Participants largely depicted teaching itself as an act of kindness, which was divided between teachers helping individual students academically (27\%) and instructing the entire class (16\%; see Figure 1 for example drawings). Participants also depicted teachers being kind at school by illustrating teachers physically helping (21\%) students. For example, depictions of kindness that involved individualized academic support were "My teacher helped me with my spelling. I messed up and she corrected me!" (\#078) and "Teacher is giving classmate ideas on what to write because they need help with their paper." (\#226). Depictions of kindness as teaching the class in general were "She is teaching. It is kind because she is helping us learn." (\#176) and "She's telling us to do our math. She helps us know stuff." (\#148). Following teaching, participants depicted teachers being kind through illustrations of teachers physically helping students (e.g., "She is getting me a band-aid when I got hurt." (\#340), "Teacher is fixing the student's scrape." (\#358) and through illustrations of teachers giving (e.g., "The teacher is giving a person an apple who doesn't have food." (\#492), "Teacher is giving another teacher a present for her baby." (068).

Analysis by gender and grade. As was done for drawing No. 1, chi square analyses were conducted to determine if gender and/or grade influenced the primary and secondary themes depicted in students' drawings of teacher kindness. Given the distribution of prevalent primary and secondary themes (see Table 3), the top three primary themes (accounting for 64\%) and the top two secondary themes (accounting for $87 \%$ ) were used for each category.

Gender did not have a significant influence on the primary theme reflected in participants' drawings, $\chi^{2}(1, N=83)=.82, p=.67$. Grade did have a significant influence on the primary theme reflected in drawings, $\chi^{2}(3, N=83)=14.92, p=.021, V=.42$ (a moderate association). Examination of the contingency table revealed that the likelihood that participants' drawings would reflect the theme of "helping academically" was not significantly different across grades (standardized residuals $z s<1.96$ ). This was also the case for the theme of "helping physically" $(z \mathrm{~s}<1.96)$. The significant influence of grade in the primary theme can be accounted for by its unusual distribution: Although teaching was a theme evident in $24 \%$ of the second-graders' drawings and $32 \%$ of the first-graders' drawings (not a significant difference, respective $z \mathrm{~S}=-.1, .7)$, this theme was evident in $54 \%$ of the kindergarten drawings $(z=2.0)$ and only in $4 \%$ of the drawings generated by third-graders $(z=-2.1)$. Gender did not have a significant influence on the secondary theme found within drawings, $\chi^{2}(1, N=105)=0.23, p=.81$, nor did grade, $\chi^{2}(3, N=105)=3.15, p=.37$.

\section{Discussion}

The findings of this study provide more information about young children's conceptual understanding of the broad notion of school kindness in several possible ways. First, the study identifies how kindness is conceptualized and represented through drawings by young students. By asking students to draw an act of kindness they had done at school recently, we are afforded a glimpse into how young children understand and interpret kind school-based behaviour. Students' drawings offer examples of how students might enact kindness - largely through acts that maintain their friendships, that physically assist others, and that show respect. Second, the findings inform our understanding of how young students perceive the prosocial behaviour of their teachers. Early elementary students are, by and large, attentive to kindness modelled by teachers and are able to identify nuanced characteristics of teachers' kind acts.

The findings here are in accord with Hamre and Pianta's (2005) interpretation of student-teacher interactions as characterized by both instructional and emotional support, and, moreover, provide examples of how teachers' behaviours reflect supporting students within 
these two categories. Participants in this study were keen observers of student-teacher interactions, noting nuanced approaches that teachers used to support students' learning (e.g., "I'm stressed about math equations and my teacher re-explained how to do it." \#159). Participants in this study also noted teachers' efforts to provide emotional support to students (e.g., "Teacher is complimenting the class and making the class feel good.” \#489).

In alignment with social learning theory (Bandura, 1986; Staub, 1992), participants' descriptions of teachers' acts of kindness revealed that they pay close attention to small details characterizing kindness modelled by teachers. Following are illustrations of the careful attention young students pay to the behaviour of their teachers: "Teacher is calling me up to pick someone's name. He also says hello in the morning." (\#508); "Teaching is showing another teacher how to do things because the other teacher does not know what they're doing." (\#518); "My teacher handed me my agenda. She didn't throw it!" (\#596); "The teacher is holding the door open for students." (\#284); and "Teacher is smiling at the class for being really good and she is laughing." (\#096).

A third finding arising from this study is that students' drawings of teachers performing kind acts at school stand to inform teacher training and practice. Haney and colleagues (2004) argue that children's drawings provide a vehicle through which teachers may reflect on their practice and learn both about their students and about themselves as educators. Young students perceive teaching itself as an act of kindness, though there is a general descending trend with third-grade students' drawings containing fewer themes of teaching as an act of kindness. This may very well reflect the increased emphasis on core subject matters (vs. instruction in social and emotional development and learning prevalent in kindergarten through second grade). This trend could also be a reflection of students' awareness of their broader learning context and the increasingly prominent role their peers play within their immediate learning community. Might this shift in students' depictions of teaching as an act of kindness reflect the emphasis older students' teachers play in helping students negotiate social relationships?

When asked to illustrate kind acts students themselves performed and ones they witnessed their teachers performing, the theme of "helping" was found across both drawings. Students' acts of kindness were characterized by physically helping others, and they perceived their teachers helping others both by providing academic support and by physically helping others. This common thread of helping across drawings might be because helping is an accessible act of kindness - it does not require materials (e.g., the provision of an object to someone in need) and typically only requires time and effort to execute. Thus, helping others is within the immediate reach of young students and teachers and is not impeded by the need for materials to enact. Further, given the robust physical, cognitive, and emotional growth that occurs in students during the elementary years and within the elementary school context, students are in a constant state of growth and struggle - in Piagetian $(1932,1936)$ terms, students regularly navigate new information and changes through assimilation and accommodation. There are thus ample opportunities to assist students in their varied states of growth and mastery.

\section{Limitations}

Research of this nature is complex to conduct, especially given the young age of the participants and the robust sample size used in this study. One component of this research required students to document information about their teachers; it was therefore necessary to have students complete this task outside the immediate purview of their classroom teacher. For some of the younger participants, especially 5- and 6-year-old kindergarten students, leaving their classroom and taking direction from unfamiliar adults may have been intimidating. Future studies examining students' conceptualizations of kindness would do well to include both a pre-visit, to establish rapport between participants and the research team, and other measures of kindness to allow for the assessment of construct validity (e.g., parent and teacher observations of students' kind acts). A second limitation of this study lies in the largely homogenous sample studied-a sample with little diversity in regards to ethnicity and second-language learners. A future study should replicate the methodology used here with a diverse population of students. Last, many of the participants' drawings were of female teachers (often depicted wearing dresses), likely reflecting their exposure to more female than male educators. A future study might examine how students' conceptualizations of both female and male teachers aligns with the current thematic findings and whether students perceive any differences in kind acts done by female and male educators.

The findings reported here inspire two future studies: First, do the prevalent themes of kindness as identified by young students reflect curricular content and/or the school's mission statement? Do their depictions of kindness reflect behaviour that is encouraged in after-school programs? That is, are students behaving kindly in ways that are explicitly encouraged within their school and broader community? Second, do teachers' conceptualizations of their and students' kindness at school mirror findings identified here? For example, do teachers perceive teaching itself to be a kind act? 
Students are encouraged and expected to be kind at school. This study informs our understanding of how students view themselves behaving kindly and how they see their teachers modelling kindness. Acts of school kindness are varied, and as noted in this study, young students pay careful attention to kindnesses done around them- from a classmate who holds a door open, to a teacher who helps a struggling student in understanding fractions. This study holds implications for both the training of new teachers and the professional development of teachers already in classrooms. Faculty who are training new teachers can incorporate strategies into their course work that illustrate how teachers might encourage and foster interpersonal prosocial behaviour among students, thereby helping to equip new teachers to foster student development and create positive classroom climates. The emotional landscape of classrooms is changing, with increased emphasis on the promotion of students' abilities to self-regulate, positively interact with peers, and effectively manage their emotions. Professional development seminars that outline the benefits to individual student well-being that arise from being kind and strategies for fostering kindness in school hold the potential to transform learning communities for all stakeholders — students, teachers, administrators, and community members alike.

Funds for the research in this article were provided by a Fall 2013 Research Grant to the author from the Central Okanagan Foundation.

\section{References}

Anderson, N. B. (2003). Emotional longevity: What really determines how long you live. New York, NY: Viking.

Andreou, E., \& Bonoti, F. (2009). Children's bullying experiences expressed through drawings and self-reports. School Psychology International, 31, 164-177. doi: 10.1177/0143034309352421

Ashdown, D. M., \& Bernard, M. E. (2012). Can explicit instruction in social and emotional learning skills benefit the social-emotional development, well-being, and academic achievement of young children? Early Childhood Education Journal, 39, 397-405. doi: 10.1007/s10643-011-0481-x

Bandura, A. (1986). Social foundations of thought and action: A social cognitive theory. Englewood Cliffs, NJ: Prentice Hall.

Binfet, J. T. (2015). Not-so random acts of kindness: A guide to intentional kindness in the classroom. International Journal of Emotional Education, 7, 35-51.

Binfet, J. T., \& Gaertner, A. (2015). Children's conceptualizations of kindness at school. Canadian Children, 40, $27-39$.

Bosacki, S., Harwood, D., \& Sumaway, C. (2012). Being mean: Children's gendered perceptions of peer teasing. Journal of Moral Education, 41, 473-489. doi: 10.1080/03057240.2012.690728

Bosacki, S., Varnish, A., \& Akseer, S. (2008). Children's gendered sense of self and play as represented through drawings and written descriptions. Canadian Journal of School Psychology, 23, 190-205. doi: 10.1177/0829573508326302

Bricheno, P., \& Thornton, M. (2007). Role model, hero, or champion? Children's views concerning role models. Educational Research, 49, 383-396.

Campos, B., \& Algoe, S. (2009). Kindness. In S. Lopez (Ed.), Encyclopedia of positive psychology (pp. 551-558). Hoboken, NJ: WileyBlackwell.

Collaborative for Academic and Social and Emotional Learning. (2015). What is social and emotional learning? Retrieved from: http:// www.casel.org/social-and-emotional-learning/

Dar, F. R. (2015). Rethinking education: Emerging roles for teachers. Universal Journal of Educational Research, 3, $63-74$.

Durlak, J. A., Weissberg, R. P., Dymnicki, A. B., Taylor, R. D., \& Schellinger, K. B. (2011). Enhancing students' social and emotional 
development promotes success in school: Results of a meta-analysis. Child Development, 82, 474-501. doi: 10.1111/j.14678624.2010.01564.x

Einarsdottir, J., Dockett, S., \& Perry, B. (2009). Making meaning: Children's perspectives expressed through drawings. Early Child Development and Care, 179, 217-232. doi: 10.1080/03004430802666999

Eisenberg, N., Fabes, R., \& Spinrad, T. (2006). Prosocial development. In W. Damon \& N. Eisenberg (Eds.), Handbook of child psychology: Social, emotional, and personality development (pp. 646-718). New York, NY: Wiley.

Eisenberg, N., Guthrie, I., Murphy, B. C., Shepard, S. A., Cumberland, A., \& Carlo, G. (1999). Consistency and development of prosocial dispositions: A longitudinal study. Child Development, 70, 1360-1372. doi: 10.1111/1467-8624.00100

Freeman, M., \& Mathison, S. (2009). Researching children's experiences. New York, NY: Guilford Press.

Gamradt, J., \& Staples, C. (1994). My school and me: Children's drawings in postmodern educational research. Visual Arts Research, $20,36-49$.

Greenberg, M., \& Turksma, C. (2015). Understanding and watering the seeds of compassion. Research in Human Development, 12, 280-287.

Guillemin, M. (2004). Understanding illness: Using drawings as a research method. Qualitative Health Research, 14, 272-289. doi: $10.1177 / 1049732303260445$

Hamre, B. K., \& Pianta, R. C. (2005). Can instructional and emotional support in the first-grade classroom make a difference for children at risk for school failure? Child Development, 76, 949-967. doi: 10.1111/j.1467-8624.2005.00889.x

Haney, W., Russell, M., \& Bebell, D. (2004). Drawing on education: Using drawings to document schooling and support change. Harvard Educational Review, 74, 241-272. doi: 10.17763/haer.74.3.w0817u84w7452011

Harwood, D., \& Copfer, S. (2015). "Your lunch pail is silly!" Children's and teachers' views on teasing. Journal of Research in Childhood Education, 29, 26-41. doi: 10.1080/02568543.2014.973126

Hsieh, H. F., \& Shannon, S. E. (2005). Three approaches to qualitative content analysis. Qualitative Health Research, 15, $1227-1288$. doi: $10.1177 / 1049732305276687$

Jennings, P. A., \& Greenberg, M. T. (2009). The prosocial classroom: Teacher social and emotional competence in relation to student and classroom outcomes. Review of Educational Research, 79, 491-524. doi: 10.3102/0034654308325693

Kerr, S. L., O’Donovan, A., \& Pepping, C. A. (2014). Can gratitude and kindness interventions enhance well-being in a clinical sample? Journal of Happiness Studies, 16, 17-36.

Lipscomb, T. J., Larrieu, J. A., McAllister, H. A., \& Bregman, N. J. (1982). Modeling and children's generosity: A developmental perspective. Merrill-Palmer Quarterly, 28, 275-282.

Long, N. J. (1997). The therapeutic power of kindness. Reclaiming Children and Youth, 5, 242-246.

Luks, A. (1988, October). Helper's high: Volunteering makes people feel good, physically and emotionally. And like "runner's calm," it's probably good for your health. Psychology Today, 22, 34-42.

Mathison, S. (2014). Seeing is believing: Using images as evidence in evaluation. In S. Donaldson, C. Christie, \& M. Mark (Eds.), Credible and actionable evidence: Foundations for rigorous and influential evaluations. Thousand Oaks, CA: SAGE.

McHugh, R. M., Galletta-Horner, C., Colditz, J. B., \& LeBaron-Wallace, T. (2013). Bridges and barriers: Adolescent perceptions of student-teacher relationships. Urban Education, 48, 9-43. doi: 10.1177/0042085912451585 
Mitchell, C., Theron, L., Stuart, J., Smith, A., \& Campbell, Z. (2011). Drawings as a research method. In L. Theron, C. Mitchell, A. Smith, \& J. Stuart (Eds.), Picturing research: Drawing as a visual methodology (pp. 19-36). Rotterdam, The Netherlands: Sense.

Peterson, C., \& Seligman, M. E. (2004). Strengths of character and well-being. Journal of Social and Clinical Psychology, 23, 603-619.

Piaget, J. (1932). The moral judgment of the child. London, England: Routledge \& Kegan Paul.

Piaget, J. (1936). Origins of intelligence in the child. London, England: Routledge \& Kegan Paul.

Pianta, R. C., La Paro, K. M., Payne, C., Cox, J. J., \& Bradley, R. (2002). The relation of kindergarten classroom environment to teacher, family, and school characteristics and child outcomes. Elementary School Journal, 102, 225-238.

Post, S. G. (2005). Altruism, happiness, and health: It's good to be good. International Journal of Behavioral Medicine, 12, 66-77.

Rea, L. M., \& Parker, R. A. (1992). Designing and conducting survey research. San Francisco, CA: Jossey-Bass.

Richer, S. (1990). Boys and girls apart: Children's play in Canada and Poland. Ottawa, ON: Carleton University Press.

Rushton, J. P. (1980). Altruism, socialization, and society. Englewood Cliffs, NJ: Prentice-Hall.

Schonert-Reichl, K. A., Hanson-Peterson, J. L., \& Hymel, S. (2015). SEL and preservice teacher education. In J. Durlak, C. Domitrovich, R. Weissberg, \& T. Gullotta (Eds.), Handbook of social and emotional learning (pp. 406-421). New York, NY: Guilford Press.

Spivak, A. L., \& Farran, D. C. (2012). First-grade teacher behaviors and children's prosocial actions in classrooms. Early Education and Development, 23, 623-639. doi: 10.1080/10409289.2011.566164

Staub, E. (1992). The origins of caring, helping, and nonaggression: Parental socialization, the family system, schools, and cultural influence. In P. M. Oliner, L. Baron, L. A. Blum, D. L. Krebs, \& M. Z. Smolenska (Eds.), Embracing the other: Philosophical, psychological, and historical perspectives on altruism (pp. 390-412). New York, NY: New York University Press.

Weber, N., Duncan, D., Dyehouse, M., Strobel, J., \& Diefes-Dux, H. A. (2011). The development of a systematic coding system for elementary students' drawings of engineers. Journal of Pre-College Engineering Education Research, 1, 49-62. doi: $10.7771 / 2157-9288.1030$

Wentzel, K. (1997). Student motivation in middle school: The role of perceived pedagogical caring. Journal of Educational Psychology, 89, 411-419. doi: 10.1037/0022-0663.89.3.411

Wolcott, H. F. (1990). Transforming qualitative data: Description, analysis, and interpretation. Thousand Oaks, CA: SAGE.

Wright, S. (2007). Graphic-narrative play: Young children's authoring through drawing and telling. International Journal of Education and the Arts, 8, 1-28.

Yurtal, F., \& Artut, K. (2010). An investigation of school violence through Turkish children's drawings. Journal of Interpersonal Violence, 25, 50-62. doi: 10.1177/0886260508329130 
Table 1: Pictorial Depictions of Drawings No. 1 and No. 2

\begin{tabular}{|c|c|c|c|c|c|}
\hline \multicolumn{6}{|c|}{ Drawing No. 1} \\
\hline Identification of Self & (n) & $\begin{array}{l}\text { Identification of } \\
\text { Individuals }\end{array}$ & (n) & Location & (n) \\
\hline Self in drawing & $\begin{array}{r}89 \% \\
(116) \\
\end{array}$ & Self alone & $\begin{array}{l}6 \% \\
(8)\end{array}$ & School general & $\begin{array}{l}44 \% \\
(57) \\
\end{array}$ \\
\hline Self not in drawing & $\begin{array}{l}11 \% \\
(14)\end{array}$ & Self + classmate & $\begin{array}{l}25 \% \\
(33)\end{array}$ & Outside & $\begin{array}{l}30 \% \\
(39)\end{array}$ \\
\hline & & Self + sibling & $\begin{array}{l}6 \% \\
(8)\end{array}$ & Playground & $\begin{array}{l}14 \% \\
(18)\end{array}$ \\
\hline & & Other & $\begin{array}{l}54 \% \\
(70)\end{array}$ & & \\
\hline \multicolumn{6}{|c|}{ Drawing No. 2} \\
\hline Identification of Self & (n) & $\begin{array}{l}\text { Identification of } \\
\text { Individuals }\end{array}$ & (n) & Location & (n) \\
\hline Self in drawing & $\begin{array}{l}38 \% \\
(49) \\
\end{array}$ & Teacher + self & $\begin{array}{l}42 \% \\
(55) \\
\end{array}$ & In classroom & $\begin{array}{r}47 \% \\
(61) \\
\end{array}$ \\
\hline \multirow[t]{4}{*}{ Self not in drawing } & $\begin{array}{l}62 \% \\
(81)\end{array}$ & Teacher alone & $\begin{array}{l}14 \% \\
(18)\end{array}$ & School general & $\begin{array}{l}38 \% \\
(49)\end{array}$ \\
\hline & & $\begin{array}{l}\text { Teacher + random } \\
\text { student }\end{array}$ & $\begin{array}{l}14 \% \\
(18)\end{array}$ & Outside & $\begin{array}{l}12 \% \\
(16)\end{array}$ \\
\hline & & Teacher + class & $\begin{array}{l}12 \% \\
(16)\end{array}$ & & \\
\hline & & $\begin{array}{l}\text { Teacher + } \\
\text { classmate } \\
\text { (identified) }\end{array}$ & $\begin{array}{l}9 \% \\
(12)\end{array}$ & & \\
\hline
\end{tabular}


Table 2: Percentage of Primary and Secondary Themes for Drawing No. 1

\begin{tabular}{|l|c|c|}
\hline \multicolumn{1}{|c|}{ Theme } & $\begin{array}{c}\text { Primary } \\
\text { Theme } \\
\text { \% (n) }\end{array}$ & $\begin{array}{c}\text { Secondary } \\
\text { Theme } \\
\text { \% (n) }\end{array}$ \\
\hline Including behaviours (e.g., initiating, welcoming, inviting) & $6(8)$ & 11 (14) \\
\hline $\begin{array}{l}\text { Friendship (e.g., activities aimed at maintaining friendships, } \\
\text { getting along) }\end{array}$ & $60(78)$ & $8(10)$ \\
\hline Showing respect (e.g., following classroom rules, being polite) & $12(16)$ & $17(22)$ \\
\hline $\begin{array}{l}\text { Helping physically (e.g., helping a student who has fallen, getting } \\
\text { a bandage for an injured student) }\end{array}$ & $10(13)$ & $20(26)$ \\
\hline $\begin{array}{l}\text { Helping emotionally (e.g., asking a lonely student if he/she is } \\
\text { okay, giving a hug to someone who is sad) }\end{array}$ & $3(4)$ & $5(7)$ \\
\hline Teaching a skill (e.g., how to kick a soccer ball) & $2(3)$ & $4(5)$ \\
\hline Protecting (e.g., standing up for others who are bullied) & $1(1)$ & $1(1)$ \\
\hline Other (e.g., being kind to the earth) & $7(9)$ & - \\
\hline No theme evident & - & $34(44)$ \\
\hline
\end{tabular}


Table 3: Percentage of Primary and Secondary Themes for Drawing No. 2

\begin{tabular}{|l|c|c|}
\hline \multicolumn{1}{|c|}{ Theme } & $\begin{array}{c}\text { Primary } \\
\text { Theme } \\
\text { \% (n) }\end{array}$ & $\begin{array}{c}\text { Secondary } \\
\text { Theme } \\
\text { \% (n) }\end{array}$ \\
\hline $\begin{array}{l}\text { Helping academically (e.g., assisting a student } \\
\text { individually, praising work) }\end{array}$ & $25(33)$ & $6(8)$ \\
\hline $\begin{array}{l}\text { Teaching (e.g., instructing the class, helping the class } \\
\text { learn) }\end{array}$ & $14(18)$ & $4(5)$ \\
\hline $\begin{array}{l}\text { Helping physically (e.g., getting a bandage, helping up } \\
\text { a student who fell) }\end{array}$ & $23(30)$ & $4(5)$ \\
\hline $\begin{array}{l}\text { Helping emotionally (e.g., being understanding, giving } \\
\text { a hug, building confidence by reassuring) }\end{array}$ & $10(13)$ & $16(21)$ \\
\hline $\begin{array}{l}\text { Providing structure (e.g., keeping routines, class clean- } \\
\text { up) }\end{array}$ & $3(4)$ & $6(8)$ \\
\hline Protecting (e.g., helping a bullied student) & $1(1)$ & - \\
\hline Playing with students (e.g., being playful) & $3(4)$ & $2(3)$ \\
\hline $\begin{array}{l}\text { Rewarding students (e.g., giving candy when class is } \\
\text { well behaved) }\end{array}$ & $3(4)$ & - \\
\hline $\begin{array}{l}\text { Giving (giving that is not rewarding- e.g., teacher } \\
\text { baked the class cookies as a surprise) }\end{array}$ & $11(14)$ & - \\
\hline $\begin{array}{l}\text { Other (e.g., teacher donated to an organization in need, } \\
\text { teacher friendly to other teachers) }\end{array}$ & $6(8)$ & 64 (83) \\
\hline No theme evident & - & \\
\hline
\end{tabular}

